\title{
대 NEPAD 지원추진 \\ (아프리카개발 이니셔티브 후속조치)
}

김성춘 참사관은 6.2 (금) $\mathrm{NEPAD}$ 사무국의 $\mathrm{L}$. Macharia 대외개발파트너십담당관을 면담, 표제 건에 대해 파악한 바, 관련사항(Macharia 담당관 언급사항) 아래 보고함.

\section{1. 우리의 대NEPAD 지원추진에 대한 NEPAD} 측 입장

- 한국정부의 '아프리카개발이니셔티브' 와 이에 따른 대 $\mathrm{NEPAD}$ 지원추진을 크게 환 영하며 한국측이 지원추진 과정에서 도움 을 필요로 하는 사항에 대해 최대한 협조하 겠음.

- $\mathrm{NEPAD}$ 는 아프리카국가들이 세계화시대에 서 아프리카대륙의 자조적이고 지속적인 발 전 방향을 모색하기 위하여 설립되었으며, 아프리카 개발지원은 holistic, integrated, co-ordinated한 접근을 요하는 점을 감안 시, $\mathrm{NEPAD}$ 는 국제사회의 아프리카 개발지
원에 있어 명실상부한 policy framework인 바, 한국의 대NEPAD 지원추진은 매우 고무 적임.

- 참고로, $\mathrm{NEPAD}$ 의 목표는 (1) 아프리카의 지 속발전 조건 확보를 위한 여건 촉진 - 평화와 안보 정착, 민주주의와 good governance(정 치, 경제, 기업 부문), 지역 협력 및 통합, 능 력개발(capacity-building), (2) 정책개혁 및 우선순위 분야에 대한 투자증대 - 농업, 인적 자원개발(특히, 보건, 교육, 과학기술 및 기 능), 인프라(ICT, 에너지, 교통, 수자원 및 위 생), 수출상품의 다양화(특히, 농산물, 공산 품, 광물, 관광 등), (3) 자원 가동 (mobilization of resources) - 국내 저축 및 투자 증대, 공공예산 관리능력 향상, 아프리 카 무역의 세계무역 비중 증대, 외국인직접 투자 유치, 부채탕감 및 $\mathrm{ODA}$ 확대를 통한 자 본 유입 증대 등임. 


\section{NEPAD의 여타 선진국으로부터의 수원동향}

\section{가. 수원 종류}

- NEPAD framework을 통한 지원은 수원주체 에 따라 NEPAD 사무국에 대한 지원인 Institutional Support와 NEPAD 산하 7개 지 역 경 제 공동체 (regional economic community)에 대한 지원인 Programmatic Support로 분류됨. 전자는 사무국의 일반 활 동에 대한 예산지원(grant)인 Budget Support와 사무국이 관장하는 프로젝트에 대 한 지원인 Sectoral Support로 구분되며, 후 자는 7 개 지역경제공동체가 추진하는 프로젝 트에 대한 공여나 자금(funding, loan 등) 지 원임.

- Institutional Support는, (1) Budget Support : NEPAD 사무국의 일반 활동에 대 한 예산지원, (2) Sectoral Support : NEPAD 사무국의 아프리카 개발을 위한 facilitator/catalyst/negotiator로서의 관장 업무, 즉 policy framework 성안, 프로그램 이행계획 작성, 이행지원(institutional arrangement for implementation) 등의 활 동에 대한 지원이며, Programmatic Support는 구체 프로젝트에 대해 원조국이 상기 지역 경제공동체(legal entity는 해당 국 가)와 직접 계약당사국이 되어 프로젝트 추진 을 지원하게 되나 NEPAD 사무국으로부터 framework/modality 마련이나 사업추진
상황에 대한 monitoring/tracking mechanism 등의 지원을 받을 수 있음.

※ Institutional Support

: Enhance Institutional Coordination Framework among the AU/NEPAD, RGEs, ADB and member States

※ Programmatic Support

: Enhance Capacity for Projects

Developments and implementation (AU/NEPAD, RGEs, ADB and member States)

- 동 지역경제공동체는 ECOWAS(Economic Community for West African States), IGAD(Inter-Governmental Authority on Development), COMESA(Common Market for Eastern and Southern African States), AMU(Arab Maghreb Union), ECCAS(Economic Community of Central African States), SADC(Southern African Development Community)임

\section{나. 수원 동향}

- NEPAD framework을 통한 지원 중 Programmatic Support는 NEPAD의 현행 제도와 규정상 관련사항에 대해 $\mathrm{NEPAD}$ 사무 국에 보고의무가 없는 관계(Programmatic Support는 계약 주체가 원조국가/국제기구와 수원국가)로 사무국도 정확한 수원 동향에 대 해 파악하지 못하고 있음. 대체로 
Programmatic Support를 포함한 원조금액 순위는 $\mathrm{G} 8, \mathrm{EU}$, 미국, 일본, 영국, 독일 등의 순으로 알고 있으나, 가능한대로 데이터를 파 악, 알려 주겠음.

- Institutional Support 관련, 2005년도의 경 우 원조국(국제기구 포함)으로부터의 수원금 액은 27.3백만 랜드(Rand, 약 445만 미불)로, 주요선진국(국제기구 제외)의 수원 규모는 스 웨덴 437만 랜드, 아일랜드 113 만 랜드, 벨기 에 110 만 랜드, 덴마크 107 만 랜드, 노르웨이 92만 랜드 등이며, $\mathrm{AU}$ 회원국 자체기여금(회 원국은 매년 최소 10 만미불 이상의 기여금 납 부의무)은 26.7 백만 랜드 (약445만미불)임.

- 일본과 중국의 경우는 각각 Programmatic Support와 양자원조(특정국가의 주요 프로 젝트에 대한 funding)가 대종을 이루고 있음.

- 한편, 국제사회의 최근 아프리카에 대한 원조 동향은 부채탕감, 긴급지원 및 선정 등의 분 야가 상대적으로 증가하고 있는데 반하여, 농 업, 보건 - 인구 분야 등은 감소하고 있는 추 세를 보이고 있는 바, 이는 주요 원조공여국 (북구국가 제외)들이 아프리카대륙의 내재적 인 필요에 대한 고려보다는 세계화시대에 있 어 국제사회의 평화와 안보 문제를 우선시하 는 시각에서 비롯되는 것으로 판단됨.

- 이에 따라, "Peace and Security", "PostConflict and Reconstruction and Development", "Good Governance" 등의
분야에 대한 원조가 증가추세에 있으며, 많은 원조국들이 수원국의 요청보다는 자국의 희 망사항 우선 반영을 요청하면서 과도한 safeguard /condition을 부과하는 관계로 기 대효과가 저상되는 경우가 상당함. 또한 인프 라 분야 원조와 관련, 프로젝트의 성격상 상 당한 규모의 지원이 장기간 요청됨에도, 원조 공여국의 원조이행이 연속성과 예측 가능성 이 확보되지 않아 사업추진 차질이 발생하는 등의 애로가 종종 발생하고 있음.

- 북구국가들은 GDP대비 원조금액도 클 뿐 아니라 수원국의 필요를 우선적으로 반영 하는 원조 행태를 보이고 있음.

\section{NEPAD측이 우선지원을 희망하는 분야 및 협력형태}

- NEPAD는 인프라분야와 농업분야(수산업 포함)에 대한 우선 지원을 희망하나, 구체적 인 우선순위는 지원규모에 따라 달려 있음. 즉, 농업분야는 상대적으로 소규모 지원규 모로 단기간 내에 성과를 나타낼 수 있는 데 반하여, 인프라분야는 대체로 지원규모가 크며 장기간의 사업기간이 소요된다는 부담 이 있음.

- 한국 측의 지원예정규모를 알 수 없어 정확 한 답변은 어려우나, Programmatic Support $75 \%$ (인프라분야 $40 \%$, 농업분야 $35 \%$, , Institutional Support 25\% 정도를 
고려해볼 수 있을 것임. Programmatic Support의 경우, legal entity의 상대방 당 사자를 해당국가로 하여 추진되는 것을 전제 로, 사업타당성 검토, framework /modality 성안 등에 대해 NEPAD 사무국 이 협조할 수 있음. 우선, 별첨 자료(NEPAD 추진 우선순위 프로젝트)상의 개별 프로젝트 를 검토한 후 관심 프로젝트에 대해 알려 주 면 상세 정보를 제공하겠음.

\section{NEPAD의 '포괄적 농업개발 프로그램' 추진 동향}

- '포괄적 농업개발 프로그램(CAADP)' 의 주 요 목표(thrust)는 (1) 지속관리 가능한 농토 확대, (2) 농업기반시설 및 생산품의 시장접 근성 향상, (3) 식량공급 확대, 기아감소 및 구급식량 비축, (4) 농업 연구조사 및 기술 향 상임.

- NEPAD는 2003.4월 상기 4대 pillar에 대한 실행계획(action plan)을 수립(별첨 $\mathrm{CAADP}$ Roadmap 참조)한 바, NEPAD flagship으 로 추진되고 있는 프로젝트는 현재 17개로 6-7년 기간 중 157 억미불의 자금소요가 계 상되어 있음. 동 실행계획 이행을 위해서는 국제사회의 중장기(5-10년) 원조/ 자금 지원 과 기술 지원을 필요로 하며, 또한, (1) 농업 분야에 대한 학문적 - 전문적 연수, (2) 전략 수립을 위한 정보기술체계, (3) PRSP과정
(Poverty Reduction Support Programme) 등에 대한 지원을 필요로 함.

- '포괄적 농업개발 프로그램' 에 대한 국제사 회의 원조는 $\mathrm{WFP}, \mathrm{IFAD}, \mathrm{FAO}$ 등의 국제기 구가 대종을 점하며 개별국가의 원조는 아직 크지 않음. 이는 구체 프로젝트가 타당성 (feasibility)이 부족하고 비효율적이라는 주 요 원조국들의 평가와 함께, 주요 선진농업 국의 자국 농업에 대한 여러 형태의 보조금 지원제도로 인하여 아프리카 농산물의 외국 시장에서의 경쟁력 저하라는 외재적 요인에 기인함.

- 그러나, 아프리카에서 농업개발은 MDGs 달성에 있어 매우 긴요한 분야이며, 최근 $\mathrm{AU}$ 가 회원국 정부예산의 $10 \%$ 를 농업분야 에 지출하기로 결정, '포괄적 농업개발 프로 그램' 은 상당히 viable한 것으로 자평하고 있음.

\section{5. 우리 정부 지원의 효율성을 제고할 수 있 는 지원분야 및 형태에 관한 남아공대사관 의견}

- 상기 $\mathrm{NEPAD}$ 측의 인프라분야 $40 \%$, 농업분 야 $35 \%$, Institutional Support 25\% 비율 참여를 염두에 두되, 우리의 $\mathrm{NEPAD}$ 에 대 한 원조가 시작단계임을 감안, 국제기구 (FAO, World Bank, WHO, UNEP, UNESCO, UNCTAD) 및 지역기구(ACBF, 
$\mathrm{ADB}, \mathrm{DBSA}$ 등)가 추진하고 있는 프로젝 트에 공동 참여하는 방안도 검토할 수 있을 것임.

- Macharia 담당관은 개인적인 의견임을 전 제로, 농업분야는 $\mathrm{SADC}, \mathrm{IGAD}, \mathrm{ECCAS}$ 지 역, 과학 기술 분야는 $\mathrm{COMESA}, \mathrm{ECA}$, ECOWAS, SADC 지역, 무역 분야는 ECOWAS지역, 무역분야는 COMESA지역, 인프라분야는 중부아프리카 지역(원유 등 자 원부국)과 $\mathrm{SADC}$ 지역(자원개발 목적의 인프 라개발 역점추진)을 우선적으로 검토할 수 있을 것이라고 언급함.

- 그러나, 우리 정부 지원의 효율성을 제고할 수 있는 지원분야 및 형태를 결정하는 문제 는 면밀하고 정확한 검토를 필요로 하는 사 안인 만큼, $\mathrm{NEPAD}$ 측과의 심도 있는 협의가 필요할 것으로 사료됨.

\section{NEPAD가 추진 중인 환경분야(생물다양 성 분야 포함) 프로젝트 현황}

- $\mathrm{AU}$ 정상회의(2003.7월)에서 채택된 'Environment Action Plan' 에 따라 환경 관련 여러 initiative가 추진되고 있으며, $\mathrm{UNEP}$ 아프리카지역사무소가 긴밀히 협조 하고 있음.

- 주요 관련프로젝트(구체사항은 별첨 자료 참 조)는 "Climate Change", "Continental Bio-fuel Program - African Research and Development", "Africa wide-Human and resource capacity Program”, "Protected Area”, "Access and Benefit Sharing”, "Achieving CBD 2010 Biodiversity Target", "Prioritization and implementation of the NEPAD Sub-regional Environment Action Plan" 등이 있음.

[자료: 주남아공대사관] 